\title{
Karakteristik dan Kinerja Penyuluh Perikanan di Kabupaten Bogor
}

\author{
[Fisheries Extension Characteristics and Performance in Bogor District]
}

\author{
Mochamad Nurdin, M. Abubakar Sidik Effendi
}

Balai Riset Perikanan Budidaya Air Tawar dan Penyuluhan Perikanan Jalan Sempur No.1, Kec.Bogor Tengah, Kota Bogor, Jawa Barat

\begin{abstract}
Abstrak
Kabupaten Bogor memiliki potensi yang cukup tinggi untuk pengembangan perikanan terutama budidaya ikan air tawar. Karakteristik dan kompetensi penyuluh perikanan dapat menentukan keefektifan kinerja penyuluh dalam penyelenggaraan penyuluhan perikanan. Penelitian ini bertujuan untuk mempelajari karakteristik serta kompetensi penyuluh perikanan dalam melaksanakan tugas dan fungsinya dalam penyelenggaraan penyuluhan perikanan di Kabupaten Bogor. Penelitian ini dilaksanakan pada bulan Januari sampai dengan Februari 2020 di Kabupaten Bogor. Metode pengumpulan data melalui pengisian kuisioner, wawancara kepada penyuluh perikanan Kabupaten Bogor sebanyak 16 orang, serta observasi lapangan. Data yang terkumpul selanjutnya dianalisis secara deskriptif. Hasil penelitian menunjukkan bahwa karakteristik penyuluh perikanan meliputi kategori pendidikan formal, pengalaman menyuluh, pelatihan, sertifikasi kompetensi, prestasi/penghargaan bidang penyuluhan mempengaruhi keefektifan kinerja penyuluh, sedangkan kategori umur dan jarak tempat tinggal/ keterjangkuan tidak mempengaruhi keefektifan kinerja penyuluh. Penyuluh perikanan Kabupaten Bogor memiliki kompetensi yang baik dalam membina kelompok perikanan, penumbuhan kelompok perikanan, peningkatan kelas kelompok perikanan, aksesibilitas legalisasi izin usaha mikro dan kecil, aksesibilitas permodalan usaha, aksesibilitas pasar, aksesibilitas informasi dan teknologi perikanan, dan aksesibilitas bantuan pemerintah.
\end{abstract}

Kata kunci: Kabupaten Bogor; karakteristik; kompetensi; penyuluh perikanan

\section{Abstract}

Bogor District has a huge fisheries resource, particularly in freshwater aquaculture. The effectiveness of fisheries extension services can determine by the characteristics and competencies of fisheries extension. This research is to study the characteristics and competencies of fisheries extension in carrying out their duties and functions in the implementation of fisheries extension in Bogor District. This research conducted from January until February 2020. Data collection of this research using questionnaires, field observations and interviews on sixteen fisheries extension. The collected data was analyzed using descriptive analysis. The results showed that the characteristics of fisheries extension such as formal education, extension experience, training, certificate of competence, achievements / awards in the field of extension affecting the effectiveness of extension performance, while age and distance of fisheries extension residence from operational fields did not affect the effectiveness of extension officer's performance. Fisheries extension in Bogor District have good competencies to foster and develop fisheries farmer groups, increase the group class based Ministerial Decree No 14/2012. Fisheries extension also have good competencies to access fisheries information and technology, grant, fisheries markets, micro and small business licenses and government assistance for fish farmers groups.

Keywords: Bogor district; characteristics; competencies; fisheries extension

Penulis Korespondensi

Mochamad Nurdin | mochamadnurdin38@yahoo.co.id 


\section{PENDAHULUAN}

Kabupaten Bogor memiliki potensi yang cukup tinggi untuk pengembangan perikanan terutama budidaya ikan air tawar. Terbitnya Kepmen KP No.32/MEN/2010 tentang penetapan kawasan minapolitan di seluruh Indonesia. Kabupaten Bogor merupakan salah satu kabupaten yang ditetapkan menjadi kawasan minapolitan oleh Kementerian Kelautan dan Perikanan. Program minapolitan merupakan kebijakan nasional yang ditetapkan oleh Kementerian Kelautan dan Perikanan dalam rangka percepatan pembangunan sektor kelautan dan perikanan.

Program minapolitan di Kabupaten Bogor sejalan dengan visi dan misi Bupati Bogor untuk merevitalisasi perikanan dengan komoditas unggulan ikan lele. Kawasan minapolitan di Kabupaten Bogor meliputi empat kecamatan yakni kecamatan ciseeng, parung, kemang, dan gunung sindur. Pengembangan perikanan di kawasan minapolitan juga berdampak kepada usaha budidaya ikan air tawar di wilayah sekitar. Peran penyuluh dan kemampuan pembudidaya ikan berkaitan erat terhadap perkembangan program minapolitan di kawasan ini (Restuwati 2013). Pangaribuan (2016) menambahkan bahwa peran penyuluh tidak dapat diabaikan dalam dunia perikanan, bagi masyarakat nelayan terutama nelayan tradisional yang minim informasi, penyuluh dapat menjadi sumber informasi yang paling tepat dan paling mudah ditemukan.

Terbitnya Undang-Undang Republik Indonesia Nomor 7 Tahun 2016 tentang perlindungan dan pemberdayaan nelayan, pembudidaya ikan, dan petambak garam pada Pasal 49 mengenai penyuluhan dan pendampingan bahwa Pemerintah Pusat sesuai dengan kewenangannya memberi fasilitas penyuluhan dan pendampingan kepada nelayan, pembudidaya ikan, dan petambak garam, termasuk keluarganya. Pada KEP.14/MEN/2012 dijelaskan bahwa penyuluhan perikanan merupakan proses pembelajaran bagi pelaku utama serta pelaku usaha agar mereka mau dan mampu menolong dan mengorganisasikan dirinya dalam mengakses informasi pasar, teknologi, permodalan, dan sumber daya lainnya sebagai upaya untuk meningkatkan produktivitas, efisiensi usaha, pendapatan, dan kesejahteraannya, serta meningkatkan kesadaran dalam pelestarian fungsi lingkungan hidup. Kegiatan penyuluhan perikanan dilaksanakan oleh penyuluh perikanan yang mempunyai ruang lingkup tugas, tanggung jawab dan wewenang untuk penyuluhan perikanan yang diduduki oleh Pegawai Negeri Sipil dengan hak dan kewajiban secara penuh yang diberikan oleh pejabat yang berwenang. Penyuluh perikanan harus 
memiliki standar kompetensi di bidang penyuluhan dan usaha perikanan dalam mencapai kinerja dengan baik. Nurmalia, Leilani, dan Zaidy (2013) menjelaskan bahwa kinerja penyuluh perikanan merupakan perwujudan diri atas sejauh mana tugas pokoknya dapat dilaksanakan sesuai dengan patokan yang telah ditetapkan. Maka, penelitian ini bertujuan untuk mempelajari karakteristik serta kompetensi penyuluh perikanan dalam melaksanakan tugas dan fungsinya dalam penyelenggaraan penyuluhan perikanan di Kabupaten Bogor.

\section{BAHAN DAN METODE}

Penelitian ini dilaksanakan pada bulan Januari sampai dengan Februari 2020 di Kabupaten Bogor. Metode pengumpulan data melalui pengisian kuisioner, wawancara kepada penyuluh perikanan Kabupaten Bogor sebanyak 16 orang, serta observasi lapangan. Parameter yang diamati adalah karakteristik penyuluh perikanan (pendidikan formal, umur, pengalaman menyuluh, pelatihan, sertifikat kompetensi, prestasi/penghargaan bidang penyuluhan, jarak tempat tinggal/ keterjangkuan), dan kompetensi penyuluh perikanan (membina kelompok perikanan, penumbuhan kelompok perikanan, peningkatan kelas kelompok perikanan, aksesibilitas legalisasi izin usaha mikro dan kecil, aksesibilitas permodalan usaha, aksesibilitas pasar, aksesibilitas informasi dan teknologi perikanan, dan aksesibilitas bantuan pemerintah) kepada pelaku utama perikanan di Kabupaten Bogor. Data yang terkumpul selanjutnya dianalisis secara deskriptif.

\section{HASIL DAN PEMBAHASAN}

Hasil

Hasil penelitian dalam mengkaji karakteristik penyuluh perikanan Kabupaten Bogor dari aspek pendidikan formal, umur, pengalaman menyuluh, pelatihan, sertifikat kompetensi, prestasi/penghargaan bidang penyuluhan, serta jarak tempat tinggal/ keterjangkauan dapat dilihat pada Tabel 1.

Hasil penelitian menggambarkan bahwa kompetensi penyuluh perikanan Kabupaten Bogor beragam dalam melakukan pembinaan kelompok perikanan, penumbuhan kelompok perikanan, serta peningkatan kelas kelompok perikanan. Lebih jelasnya dapat dilihat pada Tabel 2.

Berdasarkan hasil penelitian bahwa kompetensi penyuluh perikanan di Kabupaten Bogor beragam dalam aksesibilitas legalisasi izin usaha mikro dan kecil (IUMK), aksesibilitas permodalan usaha, aksesibilitas pasar, aksesibilitas informasi dan teknologi 
Tabel 1. Karakteristik penyuluh perikanan di Kabupaten Bogor

\begin{tabular}{|c|c|c|c|}
\hline Karakteristik & Kategori & Jumlah & Persentase (\%) \\
\hline \multirow{4}{*}{$\begin{array}{l}\text { Pendidikan } \\
\text { Formal }\end{array}$} & Magister (S2) & 5 & 31.25 \\
\hline & Sarjana/Diploma IV (S1/DIV) & 9 & 56.25 \\
\hline & Diploma III (D III) & 1 & 6.25 \\
\hline & SUPM & 1 & 6.25 \\
\hline \multirow[t]{3}{*}{ Umur } & Tua ( $\geq 55$ tahun) & 5 & 31.25 \\
\hline & Sedang ( $34-54$ tahun) & 8 & 50.00 \\
\hline & Muda ( $\leq 33$ tahun) & 3 & 18.75 \\
\hline \multirow{3}{*}{$\begin{array}{l}\text { Pengalaman } \\
\text { Menyuluh }\end{array}$} & Rendah ( $\leq 5$ tahun) & 0 & 0.00 \\
\hline & Sedang (6-10 tahun) & 9 & 56.25 \\
\hline & Tinggi ( $\geq 11$ tahun) & 7 & 43.75 \\
\hline \multirow[t]{5}{*}{ Pelatihan } & Teknik Penyuluhan & 1 & 6.25 \\
\hline & Teknik Budidaya+Pengolahan & 0 & 0.00 \\
\hline & Teknik Budidaya+Penyuluhan & 7 & 43.75 \\
\hline & Teknik Pengolahan+Penyuluhan & 1 & 6.25 \\
\hline & $\begin{array}{l}\text { Teknik } \\
\text { Budidaya+Pengolahan+Penyuluhan }\end{array}$ & 7 & 43.75 \\
\hline \multirow{6}{*}{$\begin{array}{l}\text { Sertifikasi } \\
\text { Kompetensi }\end{array}$} & Budidaya & 4 & 25.00 \\
\hline & Pengolahan & 4 & 25.00 \\
\hline & Penyuluhan & 3 & 18.75 \\
\hline & Budidaya + Penyuluhan & 3 & 18.75 \\
\hline & Pengolahan + Penyuluhan & 1 & 6.25 \\
\hline & Belum Memiliki & 1 & 6.25 \\
\hline \multirow{4}{*}{$\begin{array}{l}\text { Prestasi/ } \\
\text { Penghargaan } \\
\text { Bidang } \\
\text { Penyuluhan }\end{array}$} & Tingkat Nasional & 2 & 12.50 \\
\hline & Tingkat Provinsi & 2 & 12.50 \\
\hline & Tingkat Kabupaten & 5 & 31.25 \\
\hline & Belum Pernah & 7 & 43.75 \\
\hline \multirow{3}{*}{$\begin{array}{l}\text { Jarak Tempat } \\
\text { Tinggal/ } \\
\text { Keterjangkuan }\end{array}$} & Dekat $(\leq 10 \mathrm{Km})$ & 4 & 25.00 \\
\hline & Sedang $(11-20 \mathrm{Km})$ & 7 & 43.75 \\
\hline & Jauh $(\geq 21 \mathrm{Km})$ & 5 & 31.25 \\
\hline
\end{tabular}

perikanan, serta aksesibilitas bantuan pemerintah kepada pelaku utama perikanan. Lebih rinci dapat dilihat pada Tabel 3. 
Tabel 2. Kompetensi penyuluh perikanan dalam pembinaan kelompok perikanan, penumbuhan kelompok perikanan, dan peningkatan kelas kelompok perikanan di Kabupaten Bogor

\begin{tabular}{|c|c|c|c|}
\hline $\begin{array}{l}\text { Kompetensi penyuluh perikanan } \\
\text { pada kelompok perikanan }\end{array}$ & Kategori & Jumlah & $\begin{array}{l}\text { Persentase } \\
(\%)\end{array}$ \\
\hline \multirow[t]{4}{*}{ Kelompok perikanan binaan } & Rendah (10 kelompok) & 3 & 18.75 \\
\hline & \multirow{2}{*}{$\begin{array}{l}\text { Sedang } \\
\text { kelompok) }\end{array}$} & 7 & 43.75 \\
\hline & & 6 & 37.50 \\
\hline & \multicolumn{2}{|l|}{ Tinggi ( $\geq 13$ kelompok) } & \\
\hline \multirow[t]{3}{*}{ Penumbuhan kelompok perikanan } & Rendah (tidak ada) & 1 & 6.25 \\
\hline & Sedang (1 kelompok) & 7 & 43.75 \\
\hline & Tinggi (2 kelompok) & 8 & 50.00 \\
\hline \multirow{3}{*}{$\begin{array}{l}\text { Peningkatan } \\
\text { perikanan }\end{array}$} & Rendah (tidak ada) & 6 & 37.50 \\
\hline & Sedang (1 kelompok) & 4 & 25.00 \\
\hline & Tinggi (2 kelompok) & 6 & 37.50 \\
\hline
\end{tabular}

Tabel 3. Kompetensi penyuluh perikanan dalam aksesibilitas legalisasi izin usaha mikro dan kecil (IUMK), aksesibilitas permodalan usaha, aksesibilitas pasar, aksesibilitas informasi dan teknologi perikanan, dan aksesibilitas bantuan pemerintah kepada pelaku utama perikanan di Kabupaten Bogor

\begin{tabular}{|c|c|c|}
\hline Kategori & Jumlah & Persentase (\%) \\
\hline \multicolumn{3}{|l|}{ Aksesibilitas legalisasi IUMK } \\
\hline Rendah (1 IUMK) & 3 & 18.75 \\
\hline Sedang (2-4 IUMK) & 10 & 62.50 \\
\hline Tinggi ( $\geq 5$ IUMK) & 3 & 18.75 \\
\hline \multicolumn{3}{|l|}{ Aksesibilitas Permodalan Usaha } \\
\hline Rendah (tidak ada) & 6 & 37.50 \\
\hline Sedang (1 -2 akad modal usaha) & 4 & 25.00 \\
\hline Tinggi ( $\geq 3$ akad modal usaha) & 6 & 37.50 \\
\hline \multicolumn{3}{|l|}{ Aksesibilitas Pasar } \\
\hline Rendah ( $\leq 1$ akad jual beli) & 2 & 12.50 \\
\hline Sedang (2-9 akad jual beli) & 10 & 62.50 \\
\hline Tinggi ( $\geq 10$ akad jual beli) & 4 & 25.00 \\
\hline \multicolumn{3}{|c|}{ Aksesibilitas Informasi dan Teknologi Perikanan } \\
\hline Rendah ( $\leq 7$ kelompok) & 2 & 12.50 \\
\hline Sedang (8 - 14 kelompok) & 10 & 62.50 \\
\hline Tinggi ( $\geq 15$ kelompok) & 4 & 25.00 \\
\hline \multicolumn{3}{|l|}{ Aksesibilitas Bantuan Pemerintah } \\
\hline Rendah ( $\leq 1$ kelompok) & 6 & 37.50 \\
\hline Sedang (2 Kelompok) & 3 & 18.75 \\
\hline Tinggi ( $\geq 3$ Kelompok) & 7 & 43.75 \\
\hline
\end{tabular}




\section{Pembahasan}

Kompetensi penyuluh adalah karakteristik yang melekat pada diri penyuluh yang menentukan keefektifan kinerja penyuluh dalam mengemban misi penyuluhan (Sumarjo, 2008 dalam Nurmalia et al. 2013). Berdasarkan hasil penelitian Murfiani (2006) dalam Haryadi, Amanah, dan Suriatna (2015) karakteristik penyuluh diduga berpengaruh adalah umur, pendidikan formal, macam institusi pendidikan formal, bidang keahlian, pendidikan non formal, pengalaman menyuluh, pengalaman usaha, konsumsi media, kekosmopolitan, pendapatan, motivasi dan dukungan organisasi.

Pendidikan formal sangat penting bagi jati diri seseorang dalam pengembangan kapasitas diri. Umumnya seseorang yang memiliki pendidikan tinggi pada bidang tertentu akan memiliki pengetahuan yang lebih baik dan lebih banyak di bidang tersebut, sehingga akan lebih mudah dan mampu mengkomunikasikan ilmu dan pengetahuannya tersebut dengan baik. Pendidikan formal penyuluh perikanan di Kabupaten Bogor relatif tinggi, penyuluh perikanan lulusan Magister sebanyak 5 orang $(31,25 \%)$, Sarjana atau Diploma IV sebanyak 9 orang (56.25\%), Diploma III sebanyak 1 orang $(6.25 \%)$ dan SUPM sebanyak 1 orang (6.25\%). Menurut Lita dan Zaidy (2016) bahwa semakin tinggi pendidikan formal, akan semakin tinggi pula kemampuannya untuk menelaah informasi yang diterima dan menerapkan inovasi yang dikenalkan kepadanya.

Umur penyuluh perikanan Kabupaten Bogor masih dalam usia produktif. Umur penyuluh perikanan mayoritas masuk kategori sedang (34 54 tahun) sebanyak 8 orang (50\%), kategori tua ( $\geq 55$ tahun) sebanyak 5 orang (31.25\%) dan jumlah penyuluh perikanan yang paling sedikit pada umur muda ( $\leq 33$ tahun) sebanyak 3 orang (18,75\%). Hal ini memperlihatkan bahwa perlunya regenerasi penyuluh perikanan dalam membangun sektor kelautan perikanan secara berkelanjutan. Meskipun menurut Lita dan Zaidy (2016) bahwa karakteristik penyuluh dari kategori umur tidak ada hubungan nyata dengan kinerja penyuluh.

Pengalaman penyuluh perikanan Kabupaten Bogor dalam menyuluh kepada pelaku utama dan/atau pelaku usaha relatif tinggi. Pengalaman menyuluh pada penyuluh perikanan Kabupaten Bogor masuk ke dalam kategori sedang (6-10 tahun) sebanyak 9 orang (56.25\%) dan tinggi ( $\geq 11$ tahun) sebanyak 7 orang (43.75\%). Pengalaman menyuluh dapat menunjang tugas dan fungsi penyuluh perikanan sebagaimana dijabarkan dalam Keputusan Menteri Kelautan dan Perikanan Republik Indonesia Nomor KEP.54/MEN/2011 
tentang petunjuk teknis jabatan fungsional penyuluh perikanan dan angka kreditnya. Hasil penelitian Lita dan Zaidy (2016) pada penyuluh perikanan swadaya bahwa pengalaman usaha sebagai salah satu faktor penting karena semakin lama pengalaman usaha, seorang penyuluh perikanan swadaya akan semakin memahami tentang budidaya ikan sehingga akan berpengalaman dan menunjang dalam melaksanakan fungsi tugasnya sebagai Penyuluh Perikanan Swadaya.

Pelatihan adalah salah satu program dalam pengembangan kompetensi aparatur. Kompetensi merupakan kemampuan dan kewenangan yang dimiliki oleh seseorang untuk melakukan suatu pekerjaan, yang didasari oleh pengetahuan, keterampilan dan sikap sesuai dengan unjuk kerja yang ditetapkan (Sumarjo 2009 dalam Haryadi et al. 2015). Berdasarkan hasil penelitian bahwa semua penyuluh perikanan Kabupaten Bogor telah mengikuti pelatihan di bidang penyuluhan perikanan. Dari 16 orang penyuluh perikanan Kabupaten Bogor, sebanyak 7 orang $(43,75 \%)$ telah mengikuti pelatihan di bidang budidaya, pengolahan, dan penyuluhan perikanan. Bentuk bukti legalitas kompetensi penyuluh perikanan yakni mendapatkan sertifikat kompetensi. Sertifikat kompetensi adalah jaminan tertulis atas penguasaan kompetensi pada bidang keahlian perikanan tertentu yang diberikan oleh satuan pendidikan dan pelatihan yang telah terakreditasi oleh lembaga yang berwenang, sebagaimana tertuang pada Kepmen KP Nomor KEP.14/MEN/2012. Mayoritas penyuluh perikanan Kabupaten Bogor telah memiliki sertifikat kompetensi pada bidang keahlian budidaya/ pengolahan/ penyuluhan, hanya satu orang penyuluh perikanan yang belum memiliki sertifikat kompetensi. Sertifikat kompetensi yang dimiliki oleh penyuluh perikanan diterbitkan oleh Badan Nasional Sertifikasi Profesi (BNSP).

Penyuluh perikanan Kabupaten Bogor telah meraih prestasi atau penghargaan atas dedikasi profesinya. Pada bidang penyuluhan perikanan telah berhasil meraih penghargaan sebagai penyuluh teladan baik di tingkat nasional, provinsi, dan kabupaten. Selain itu, penyuluh perikanan Kabupaten Bogor juga pernah meraih penghargaan sebagai pelayan ketahanan pangan di tingkat Kabupaten Bogor dan penghargaan lomba karya tulis ilmiah penyuluh perikanan di tingkat Provinsi Jawa Barat.

Umumnya keterjangkauan atau jarak tempat tinggal penyuluh perikanan dengan wilayah kerja tidak menjadi kendala dalam melaksanakan tugas dan fungsinya, hal ini karena adanya motivasi tinggi yang dimiliki penyuluh perikanan Kabupaten Bogor. Penelitian Kamsiah 
(2015) bahwa terdapat hubungan positif antara kompetensi penyuluh dan motivasi kerja secara bersama-sama dengan produktivitas kerja penyuluh. Berdasarkan hasil penelitian bahwa jarak tempat tinggal penyuluh perikanan Kabupaten Bogor dengan wilayah kerja mayoritas ke dalam kategori sedang hingga jauh. Lita dan Zaidy (2016) menambahkan bahwa faktor karakteristik eksternal Penyuluh Perikanan Swadaya yang mempengaruhi kinerja adalah pemanfaatan sarana dan prasarana serta dukungan biaya, yang tidak mempengaruhi adalah penghargaan dan jarak tempat tinggal/keterjangkauan.

$$
\text { Undang-Undang }
$$

Republik Indonesia Nomor 7 Tahun 2016 tentang perlindungan dan pemberdayaan nelayan, pembudidaya ikan, dan petambak garam menyebutkan bahwa penyediaan penyuluh paling sedikit terdiri atas 3 (tiga) orang penyuluh dalam 1 (satu) kawasan potensi kelautan dan Perikanan. Kabupaten Bogor terdiri atas 40 kecamatan, sedangkan saat ini hanya ada 16 orang penyuluh perikanan. Wilayah kerja penyuluh perikanan Kabupaten Bogor pada satu hingga dua kecamatan yang berpotensi dalam pengembangan perikanan, dan ada beberapa kecamatan tidak ada penyuluh perikanan. Hal senada disampaikan oleh Pangaribuan (2016) bahwa satu penyuluh harus menangani satu hingga dua kecamatan, bahkan lebih, sehingga belum semua wilayah dapat merasakan keberadaan penyuluh. Nurmalia et al. (2013) menambahkan bahwa penyuluh perikanan berdasarkan kondisi di lapangan masih kurang, keberadaan penyuluh perikanan dalam kegiatan penyuluhan kepada pelaku usaha masih sangat diperlukan.

Kelembagaan pelaku utama perikanan di Kabupaten Bogor yang dibina oleh penyuluh perikanan berbentuk kelompok pembudidaya ikan (POKDAKAN) dan kelompok pengolah dan pemasar ikan (POKLAHSAR). Fungsi kelompok sesuai dengan Kepmen KP Nomor 14 Tahun 2012 tentang Pedoman Umum Penumbuhan dan Pengembangan Kelembagaan Pelaku Utama Perikanan, terdiri atas delapan fungsi yaitu wadah proses pembelajaran, wahana kerjasama, unit penyedia sarana dan prasarana produksi perikanan, unit produksi perikanan, unit pengolahan dan pemasaran, unit jasa penunjang, organisasi kegiatan bersama, dan kesatuan swadaya dan swadana. Undang-Undang Republik Indonesia Nomor 7 Tahun 2016 tentang perlindungan dan pemberdayaan nelayan, pembudidaya ikan, dan petambak garam mengamanahkan bahwa Pemerintah Pusat dan Pemerintah Daerah sesuai dengan kewenangannya melakukan pembinaan untuk pengem- 
bangan kelembagaan yang telah terbentuk serta mendorong dan memfasilitasi terbentuknya kelembagaan.

Penyuluh perikanan Kabupaten Bogor berperan aktif dalam membina kelompok perikanan secara berkelanjutan. Sebagaimana dijelaskan pada Kepmen KP Nomor KEP.14/MEN/2012 bahwa kunjungan pembinaan kepada sasaran kelompok merupakan metode penyuluhan perikanan langsung dengan mendatangi pertemuan kelompok baik yang rutin maupun yang insidentil dalam rangka memberdayakan kelompok pelaku utama/pelaku usaha perikanan. Peran penyuluh membantu perkembangan dan kemajuan kelembagaan kelompok (Restuwati 2013). Penyuluh perikanan membina kelompok perikanan minimal 10 kelompok perikanan. Kelompok perikanan ini memiliki anggota minimal 10 orang, artinya seorang penyuluh perikanan membina pelaku utama perikanan minimal sebanyak 100 orang. Hal ini diduga bahwa keberadaan kelompok perikanan sangat membantu penyuluh perikanan dalam penyelenggaraan penyuluhan perikanan yang efektif dan efesien. Kurniawan dan Triyanti (2011) menjelaskan bahwa kelembagaan yang sebaiknya ada adalah kelompok pembudidaya, keuntungan adanya kelompok pembudidaya ini adalah mempermudah penyuluh lapangan mengadakan penyuluhan, para penyuluh bisa bertukar pikiran dengan pembudidaya agar pembudidaya bisa melakukan cara budidaya ikan yang baik (CBIB) dan benar sehingga jumlah kuantitas dan kualitas produksi akan memenuhi persyaratan.

Dalam pembinaan kelompok perikanan, penyuluh perikanan juga mengajak dan bekerjasama dengan Dinas Perikanan dan Peternakan Kabupaten Bogor, peneliti, dan aparatur Kementerian Kelautan dan Perikanan. Hal yang sama dikemukakan Nurdin (2018) bahwa pola pengembangan kelembagaan pelaku utama perikanan yang dilakukan oleh penyuluh perikanan bekerjasama dan bersinergi dengan pihak-pihak terkait (Dinas Peternakan dan Perikanan, peneliti, dosen, dan tenaga ahli) yang kompeten sesuai dengan substansi materi pembinaan yang dibutuhkan. Peran penyuluh memberikan bimbingan rutin dan berperan aktif menggerakkan dan memajukan kelompok berpengaruh signifikan terhadap perkembangan minapolitan (Restuwati 2013). Menurut Hermawan, Amanah, dan Fatchiya (2017) partisipasi aktif anggota dalam kelompok diperlukan karena pembudidayalah yang pada akhirnya berperan dalam melaksanakan kegiatan kelompok dan sifat saling ketergantungan antara anggota dengan kelompok (interdependent). Rosiah dan Hasan (2018) menambahkan bahwa 
pembudidaya ikan yang aktif terlibat dalam pelaksanaan penyuluhan perikanan, akan selau termotivasi untuk melakukan apa yang dianjurkan oleh penyuluh perikanan sehingga kompetensinya semakin baik.

Penyuluh perikanan Kabupaten Bogor mampu melakukan penumbuhan kelompok perikanan. Berdasarkan hasil penelitian bahwa hampir semua penyuluh perikanan melakukan penumbuhan sebanyak satu hingga dua kelompok perikanan dalam satu tahun, dan hanya satu penyuluh perikanan yang tidak melakukan penumbuhan kelompok. Kelompok perikanan yang ditumbuhkan adalah kelompok pembudidaya ikan. Menurut Hermawan et al. (2017) bahwa pembudidaya menyatakan dorongan utama bergabung dalam kelompok atas dasar kebutuhan usaha, kesadaran dan keinginan sendiri. Motif ekonomi dan sosial mendominasi keterlibatannya, yakni kemudahan akses informasi, kemudahan pemenuhan sarana produksi, memperoleh solusi masalah usaha, menambah mitra dan kerjasama, kemudahan pemasaran, termasuk memperoleh modal dan bantuan program. Ada beberapa tahapan yang dilakukan oleh penyuluh perikanan dalam penumbuhan kelompok perikanan diantaranya (1) mengidentifikasi potensi perikanan di wilayah setempat; (2) pertemuan dalam rangka sosialisasi penumbuhan kelompok perikanan kepada masyarakat dan aparatur desa tentang hasil identifikasi potensi wilayah; (3) pertemuan yang dihadiri oleh pelaku utama perikanan, penyuluh perikanan, dan kepala/aparatur desa setempat dalam rangka pengukuhan pembentukan kelompok perikanan serta menyusun struktur organisasi dan dibuat berita acara pembentukan kelompok perikanan; (4) penerbitan Surat Keputusan pengukuhan pembentukan kelompok perikanan yang disahkan oleh kepala desa setempat; (5) Surat Keputusan pengukuhan pembentukan kelompok perikanan selanjutnya di laporkan ke Balai Riset Perikanan Budidaya Air Tawar dan Penyuluhan Perikanan serta Dinas Perikanan dan Peternakan Kabupaten Bogor.

Penyuluh perikanan di Kabupaten Bogor melakukan peningkatan kelas kemampuan kelompok perikanan (Tabel 2). Peningkatan kemampuan kelembagaan pelaku utama dan/atau pelaku usaha merupakan kegiatan pembinaan kelembagaan untuk meningkatkan kemampuan manajerial, teknis, ekonomis dan sosial. Hasil penelitian memperlihatkan bahwa kelompok perikanan yang ditingkatkan berasal dari kelas pemula menjadi kelas madya, dan belum ada kelompok perikanan yang ditingkatkan dari kelas madya dan menjadi kelas utama. Kriteria 
dan indikator penilaian kelembagaan pelaku utama perikanan berdasarkan Kepmen KP No. 14 Tahun 2012 terdiri dari aspek (1) kemampuan perencanaan (identifikasi potensi wilayah, teknologi perikanan, menyusun rencana usaha kegiatan, dan pembinaan kader); (2) kemampuan berorganisasi (kerjasama dengan pihak lain, monitoring dan evaluasi); (3) akses kelembagaan (ekonomi, jaringan eletronik, komunikasi, dan teknologi); (4) kemampuan wirausaha (memupuk modal usaha, pengembangan usaha dan pemasaran); serta (5) kemandirian (inovasi, mengelola resiko usaha dan pemecahan masalah). Leilani dan Hermawan (2010) menambahkan bahwa pendekatan kelompok memiliki pengaruh yang sangat nyata terhadap keberdayaan pembudidaya terutama dalam peningkatan pengetahuan keterampilan sikap pembudidaya, peningkatan produksi dan kemandirian pembudidaya dalam pengambilan keputusan.

Undang-Undang Republik Indonesia Nomor 7 Tahun 2016 tentang perlindungan dan pemberdayaan nelayan, pembudidaya ikan, dan petambak garam pada Pasal 52 bahwa Pemerintah Pusat dan Pemerintah Daerah sesuai dengan kewenangannya berkewajiban memberikan kemudahan akses ilmu pengetahuan, teknologi, dan informasi. Berdasarkan hasil penelitian bahwa peran penyuluh perikanan Kabupaten Bogor tidak hanya memberikan akses ilmu pengetahuan, teknologi dan informasi, juga berperan dalam aksesibilitas legalisasi izin usaha mikro dan kecil (IUMK), aksesibilitas permodalan usaha, aksesibilitas pasar, serta aksesibilitas bantuan pemerintah kepada pelaku utama/usaha perikanan di Kabupaten Bogor (Tabel 3). Hasil penelitian Nurmalia et al. 2013) menambakan bahwa pelaku usaha masih mengharapkan bantuan penyuluh perikanan, dengan jenis bantuan yang diharapkan adalah yang tertinggi pada kategori meningkatkan produksi $42 \%$, sementara pada kategori mencarikan bantuan modal dari pemerintah dan kategori membantu memasarkan hasil produksi masing-masing $22 \%$ dan $21 \%$.

Penyuluh perikanan kompeten dalam aksesibilitas legalisasi izin usaha mikro dan kecil (IUMK) kepada pelaku utama perikanan di Kabupaten Bogor (Tabel 3). Hasil penelitian menunjukkan bahwa mayoritas penyuluh perikanan di Kabupaten Bogor berperan dalam aksesbilitas legalisasi sebanyak dua hingga empat IUMK. Berdasarkan Perpres Nomor 98 Tahun 2014 bahwa izin usaha mikro dan kecil yang selanjutnya disingkat dengan IUMK adalah tanda legalitas kepada seseorang atau pelaku usaha/kegiatan tertentu 
dalam bentuk izin usaha mikro dan kecil dengan tujuan untuk mendapatkan kepastian dan perlindungan dalam berusaha dilokasi yang telah ditetapkan, mendapatkan pendampingan untuk pengembangan usaha, mendapatkan kemudahan dalam akses pembiayaan ke lembaga keuangan bank dan non-bank, dan mendapatkan kemudahan dalam pemberdayaan dari pemerintah, pemerintah daerah dan/atau lembaga lainnya.

Penyuluh perikanan berperan dalam aksesibilitas permodalan usaha perikanan bagi pelaku utama perikanan di Kabupaten Bogor. Menurut Haryadi et al. (2015) bahwa pembudidaya ikan membutuhkan kemudahan dalam mengakses permodalan untuk mengembangkan usahanya, akses permodalan usaha umumnya di bankbank komersial dan Corporate Social Responsibility (CSR). Berdasarkan hasil penelitian bahwa sumber permodalan usaha perikanan yang diakses oleh penyuluh perikanan Kabupaten Bogor berasal dari lembaga keuangan/Bank komersial melalui program kredit usaha rakyat (KUR) dari BRI dan Bank Mandiri, program Corporate Social Responsibility (CSR) dari PT. Antam (Persero) Tbk, dan koperasi. Hasil penelitian Nurmalia et al. (2013) menjelaskan bahwa persepsi pelaku usaha terhadap harapan adanya kelompok usaha perikanan menunjukkan bahwa kategori memberi informasi cara produksi dengan persentase yang paling tinggi (35\%), walaupun persepsi terhadap pengadaan benih dan pakan serta persepsi membantu memasarkan hasil masing-masing juga dengan persentase yang sama tinggi (25\%), dan memberi pinjaman modal (15\%).

Aksesibilitas pasar bagi pelaku utama/usaha perikanan bertujuan untuk mendorong meningkatkan produksi serta pendapatan. Pada Kepmen KP Nomor KEP.14/MEN/2012 dijelaskan bahwa kemitraan usaha kelompok dengan swasta merupakan pola kerja sama antara pelaku utama dengan swasta yang dituangkan dalam bentuk ikatan kerjasama dalam rangka penyediaan dukungan dan kemudahan untuk pengembangan usaha ekonomi produktif kelompok untuk mendukung pengembangan perekonomian anggota, yang bertujuan untuk menciptakan iklim usaha kondusif, meningkatkan akses pada sumber daya finansial dan akses pasar. Menurut Triyanti dan Shafitri (2012) bahwa pemasaran produk adalah satu komponen pasca produksi yang perlu mendapatkan perhatian lebih karena pemasaran merupakan salah satu kunci dalam pengembangan usaha. Berdasarkan hasil penelitian bahwa penyuluh perikanan berperan aktif dalam aksesibilitas pasar kepada kelompok perikanan di Kabupaten Bogor (Tabel 3). 
Aksesbilitas pasar pasca produksi ini kepada kelompok perikanan lain, pedagang pengumpul, dan swasta dengan cakupan wilayah dalam dan luar Kabupaten Bogor. Triyanti dan Shafitri (2012) menambahkan bahwa lembaga pemasaran yang terlibat dalam pendistribusian ikan lele adalah pedagang pengumpul (dalam dan luar kabupaten), dan pedagang pengecer (dalam dan luar kabupaten) usaha.

Penyuluh perikanan berperan aktif dalam aksesibilitas informasi dan teknologi perikanan kepada kelompok perikanan di Kabupaten Bogor (Tabel 3). Informasi dan teknologi perikanan yang disampaikan berupa teknologi perikanan budidaya, teknologi pengolahan hasil perikanan, aspek manajemen, informasi permodalan usaha, informasi pendidikan, dll. Menurut Restuwati (2013) bahwa peran penyuluh dan kemampuan pembudidaya ikan dalam mengakses informasi berpengaruh terhadap perkembangan program minapolitan di kawasan Kabupaten Bogor. Pangaribuan (2016) menambahkan bahwa peran penyuluh sebagai sumber informasi bagi masyarakat nelayan sangat besar, penyuluh yang dibekali dengan informasi yang cukup akan sangat membantu nelayan dalam meningkatkan produktivitasnya.

Penyuluh perikanan kompeten dalam aksesibilitas bantuan pemerintah kepada kelompok perikanan di Kabupaten Bogor. Hasil penelitian bahwa penyuluh perikanan mampu mengakses paling banyak tiga jenis bantuan pemerintah dalam satu tahun. Bantuan pemerintah bersumber dari pemerintah pusat (Kementerian Kelautan dan Perikanan), pemerintah daerah Kabupaten Bogor, dan Badan Usaha Milik Desa (BUMDES). Dari analisis karakteristik jejaring komunikasi kelompok menunjukkan bahwa peran penyuluh perikanan berkaitan erat dengan tingkat perkembangan program bantuan minapolitan di Kecamatan Ciseeng Kabupaten Bogor (Restuwati 2013).

\section{SIMPULAN DAN SARAN}

Karakteristik penyuluh perikanan meliputi kategori pendidikan formal, pengalaman menyuluh, pelatihan, sertifikasi kompetensi, prestasi/ penghargaan bidang penyuluhan mempengaruhi keefektifan kinerja penyuluh, sedangkan kategori umur dan jarak tempat tinggal/ keterjangkuan tidak mempengaruhi keefektifan kinerja penyuluh. Penyuluh perikanan Kabupaten Bogor memiliki kompetensi yang baik dalam membina kelompok perikanan, penumbuhan kelompok perikanan, peningkatan kelas kelompok perikanan, aksesibilitas legalisasi izin usaha mikro dan kecil, aksesibilitas 
permodalan usaha, aksesibilitas pasar, aksesibilitas informasi dan teknologi perikanan, dan aksesibilitas bantuan pemerintah.

\section{DAFTAR PUSTAKA}

Haryadi, Ikhsan, Siti Amanah, dan Suwardi Suriatna. 2015. "Persepsi Pembudidaya Ikan Terhadap Kompetensi Penyuluh Perikanan di Kawasan Minapolitan (Kasus di Kabupaten Cirebon, Provinsi Jawa Barat)." Jurnal Penyuluhan 10(2). doi:

10.25015/penyuluhan.v10i2.9920.

Hermawan, Aan, Siti Amanah, dan Anna Fatchiya. 2017. "Partisipasi Pembudidaya Ikan dalam Kelompok Usaha Akuakultur di Kabupaten Tasikmalaya." Jurnal Penyuluhan 13(1):1. doi: 10.25015/penyuluhan.v13i1.12903.

Kurniawan, Tikkyrino, dan Riesti Triyanti. 2011. "Profil Usaha Budidaya Ikan Lele di Kabupaten Bogor." Buletin IImiah Marina Sosial Ekonomi Kelautan dan Perikanan 6(2):40. doi: 10.15578/marina.v6i2.5812.
Leilani, Ani, dan Aan Hermawan. 2010. "Pengaruh Pendekatan Kelompok Terhadap Keberdayaan Pembudidaya (Kasus di Kabupaten Sleman Provinsi Daerah Istimewa Yogyakarta)." Jurnal Penyuluhan Perikanan dan Kelautan 4(2):5367. doi: 10.33378/jppik.v4i2.18.

Lita, Noor Piito Sari Nio, dan Azam Bachur Zaidy. 2016. "Kinerja Penyuluh Perikanan Swadaya di Kabupaten Bogor." Jurnal Penyuluhan Perikanan dan Kelautan 10(3):150-63. doi: 10.33378/jppik.v10i3.75.

Nurdin, M. 2018. "Perkembangan Kelembagaan Pelaku Utama Perikanan di Kecamatan Cijeruk Kabupaten Bogor." in Prosiding Seminar Nasional Perikanan dan Penyuluhan 2018, diedit oleh W. Hadie. Bogor (ID): Masyarakat Iktiologi Indonesia.

Nurmalia, Nayu, Ani Leilani, dan Azam B.

Zaidy. 2013. "Persepsi Pelaku Usaha Perikanan Terhadap Kinerja Penyuluh Perikanan." Jurnal Penyuluhan Perikanan dan Kelautan 7(1):16-25. doi: 10.33378/jppik.v7i1.35. 
Pangaribuan, Tristania Risma Anastasia. 2016. "Mengembangkan Peran Edukasi dan Diseminasi Informasi oleh Penyuluh Perikanan Bagi Masyarakat Nelayan di Kabupaten Serdang Bedagai." Jurnal Penelitian Komunikasi dan Pembangunan 17(1):61-75.

Restuwati, Ina. 2013. "Hubungan Peran Penyuluh Perikanan dan Kemampuan Akses Media Informasi Pembudidaya Ikan Terhadap Perkembangan Program Minapolitan di Kecamatan Ciseeng Bogor." Jurnal Penyuluhan Perikanan dan Kelautan 7(1):92106. doi: 10.33378/jppik.v7i1.42.
Rosiah, Erlin, dan O. D. Soebhakti Hasan. 2018. "Analisis Penyuluhan Perikanan Partisipatif dan Kompetensi Pembudidaya Ikan di Kabupaten Sumedang." Jurnal Penyuluhan Perikanan dan Kelautan 12(1):47-63.

Triyanti, Riesti, dan Nensyana Shafitri. 2012. "Kajian pemasaran ikan lele (Clarias Sp) dalam mendukung industri perikanan budidaya (studi kasus di Kabupaten Boyolali, Jawa Tengah)." Jurnal Sosial Ekonomi Kelautan dan Perikanan 7(2):17791. doi: 10.15578/jsekp.v7i2.5684. Undang-Undang Republik Indonesia Nomor 7 Tahun 2016 tentang Perlindungan dan Pemberdayaan Nelayan, Pembudidaya Ikan, dan Petambak Garam. 